\title{
Synthetic Chemical Probes That Dissect Vitamin D Activities
}

\section{AUTHOR(S):}

Nagata, Akiko; Akagi, Yusuke; Asano, Lisa; Kotake, Kenjiro; Kawagoe, Fumihiro; Mendoza, Aileen; Masoud, Sedghi, Shadi; ... Kittaka, Atsushi; Nagasawa, Kazuo; Uesugi, Motonari

\section{CITATION:}

Nagata, Akiko ... [et al]. Synthetic Chemical Probes That Dissect Vitamin D Activities. ACS chemical biology 2019, 14(12): 2851-2858

\section{ISSUE DATE:}

2019-12-20

\section{URL:}

http://hdl.handle.net/2433/252796

\section{RIGHT:}

This document is the Accepted Manuscript version of a Published Work that appeared in final form in ACS chemical biology, copyright (C) American Chemical Society after peer review and technical editing by the publisher. To access the final edited and published work see https://doi.org/10.1021/acschembio.9b00718.; The full-text file will be made open to the public on 16 October 2021 in accordance with publisher's 'Terms and Conditions for Self-Archiving'.; This is not the published version. Please cite only the published version.; この論文は出版社版でありません。引用の際には出版社 版をご確認ご利用ください。 


\title{
Synthetic Chemical Probes That Dissect Vitamin D Activities
}

\author{
Akiko Nagata, ${ }^{\S, \dagger}$ Yusuke Akagi, ${ }^{\S, \dagger}$ Lisa Asano,${ }^{\jmath \dagger}$ Kenjiro Kotake, ${ }^{\jmath}$ Fumihiro Kawagoe, ${ }^{\ddagger}$ Aileen Mendoza,
} Shadi Sedghi Masoud, ${ }^{\S}$ Kosuke Usuda, ${ }^{\S}$ Koji Yasui, ${ }^{\S}$ Yasushi Takemoto, Atsushi Kittaka, ${ }^{\ddagger} *$ Kazuo Nagasawa, ${ }^{\S, *}$ and Motonari Uesugi ${ }^{1}, \ldots, \$, *$

\$Department of Biotechnology and Life Science, Graduate School of Technology, Tokyo University of Agriculture and Technology, 2-24-16, Naka-cho, Koganei city, 184-8588, Tokyo, Japan

Institute for Chemical Research, Kyoto University, Uji, Kyoto 611-oo11, Japan

‡Faculty of Pharmaceutical Sciences, Teikyo University, 2-11-1 Kaga, Itabashi, Tokyo 173-8605, Japan

"Institute for Integrated Cell-Material Sciences (WPI-iCeMS), Kyoto University, Uji, Kyoto 611-oo11, Japan

${ }^{€}$ CREST, AMED

${ }^{\$}$ School of Pharmacy, Fudan University, Shanghai 201203, China

\begin{abstract}
Vitamin $\mathrm{D}_{3}$ metabolites are capable of controlling gene expression in mammalian cells through two independent pathways: vitamin D receptor (VDR) and sterol regulatory element-binding protein (SREBP) pathways. In the present study, we dissect the complex biological activity of vitamin D by designing synthetic vitamin $\mathrm{D}_{3}$ analogs specific for VDR or SREBP pathway, i.e., a VDR activator that lacks SREBP inhibitory activity, or an SREBP inhibitor devoid of VDR activity. These synthetic vitamin D probes permitted identification of one of the vitamin D-responsive genes, Soat1, as an SREBP-suppressed gene. The chemical probes developed in the present study may prove useful in dissecting the intricate interplay of vitamin D actions, thereby providing insights into how vitamin D target genes are regulated.
\end{abstract}

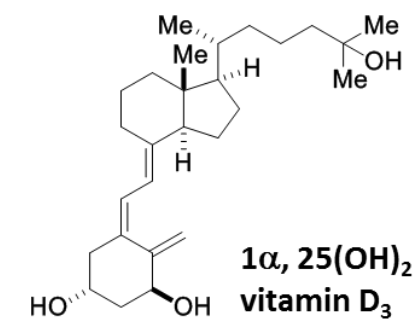

VDR

activation
SREBP

inhibition

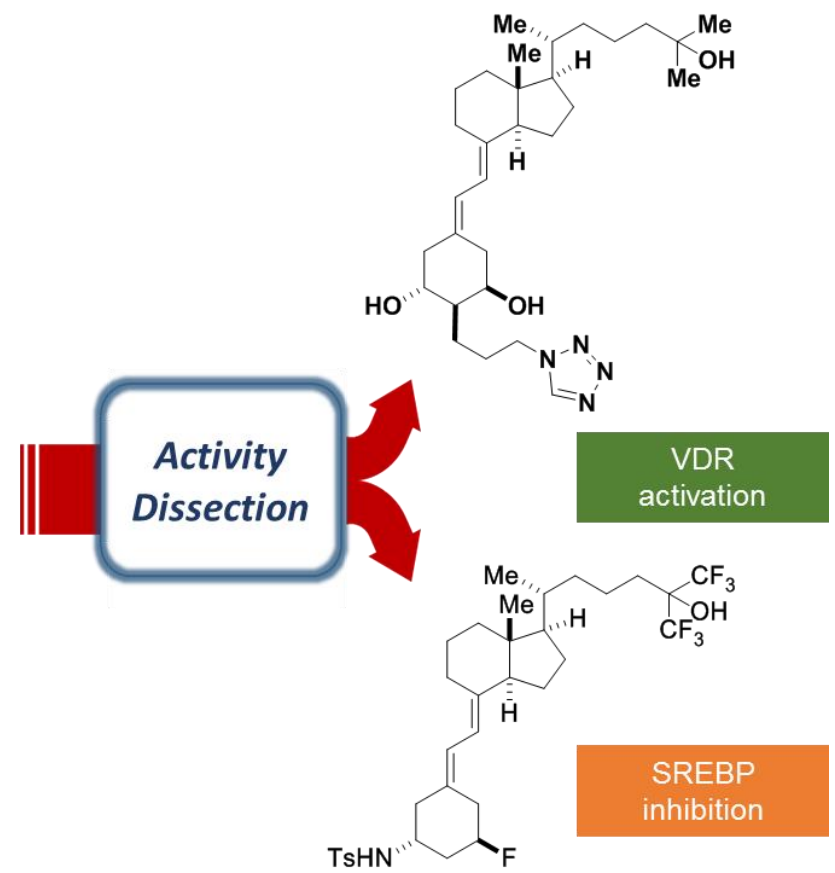




\section{- Introduction}

Vitamin $\mathrm{D}_{3}$ [cholecalciferol, $\mathrm{VD}_{3}(\mathbf{1})$ ] is a lipophilic vitamin present in foods and also endogenously synthesized from 7-dehydrocholesterol following the exposure to sunlight. In humans, $\mathrm{VD}_{3}$ is converted by CYP enzymes to 25-hydroxyvitamin $\mathrm{D}_{3}\left[25(\mathrm{OH}) \mathrm{D}_{3}(2)\right]$ and $1 \alpha, 25$-dihydroxyvitamin $\mathrm{D}_{3}\left[1 \alpha, 25(\mathrm{OH})_{2} \mathrm{D}_{3}\right.$ (3)] (Fig. 1), exerting a range of physiological activities including calcium metabolism, ${ }^{1}$ cellular differentiation, ${ }^{2}$ and immune regulation. ${ }^{3}$ Many of these physiological activities can be explained by the binding of $1 \alpha, 25(\mathrm{OH})_{2} \mathrm{D}_{3}$ to the vitamin $\mathrm{D}$ receptor (VDR), a nuclear receptor that controls the gene expression. ${ }^{4}$ This well-recognized mechanism of vitamin D action has been well investigated for many years since the cloning of chick VDR in $1987 .{ }^{5}$

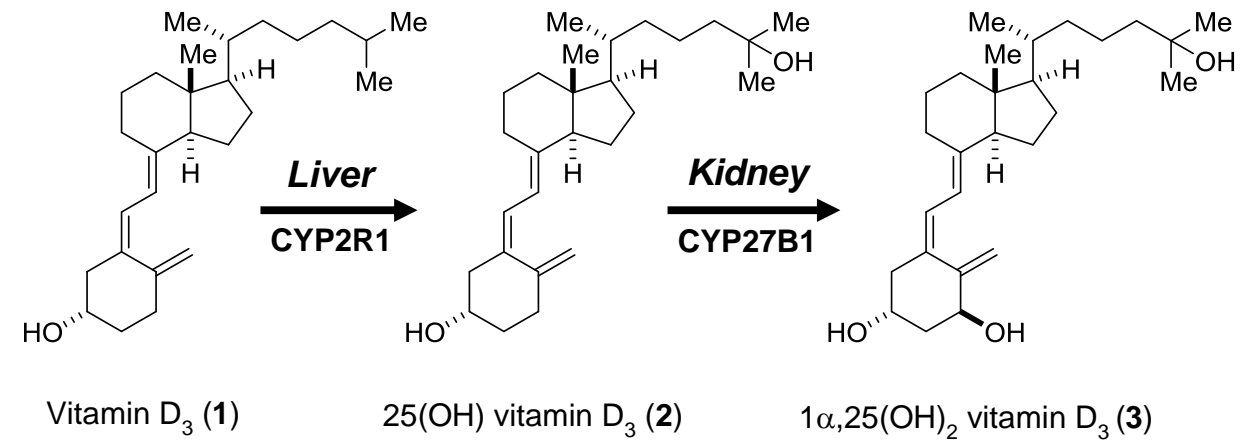

Figure 1. Structures of vitamin $\mathrm{D}_{3}(\mathbf{1}), 25(\mathrm{OH})$ vitamin $\mathrm{D}_{3}(\mathbf{2})$ and $1 \alpha, 25(\mathrm{OH})_{2}$ vitamin $\mathrm{D}_{3}(\mathbf{3})$.

On the other hand, vitamin D metabolites have also been reported to exert effects independent from VDR activation. ${ }^{6-19}$ For example, growth inhibition and induction of apoptosis by $1 \alpha, 25(\mathrm{OH})_{2} \mathrm{D}_{3}$ in breast cancer cells ${ }^{7}$ persisted in VDR-knockout mice. $1 \alpha, 25(\mathrm{OH})_{2} \mathrm{D}_{3}$ has been shown to interact with MARRS (membrane-associated rapid response steroid binding protein) for precise regulation of phosphate uptake. ${ }^{8}$ Two minor vitamin $\mathrm{D}$ metabolites, 20-hydroxyvitamin $\mathrm{D}_{3}$ and 20,23 -dihydroxyvitamin $\mathrm{D}_{3},{ }^{9-12}$ have also been reported as agonists or antagonists of non-VDR nuclear receptors. ${ }^{13-16}$ However, detailed mechanisms or biological significance underlying these VDR-independent activities remain unclear.

Recently, we found that the most abundant $\mathrm{VD}_{3}$ metabolite, $25(\mathrm{OH}) \mathrm{D}_{3}$, down-regulates SREBP (sterol regulatory element-binding protein) independently of VDR. ${ }^{19}$ SREBP is a non-nuclear receptor transcription factor that activates genes associated with cholesterol and fatty acid biosynthesis. ${ }^{20-23}$ SREBP is expressed on the membrane of the endoplasmic reticulum (ER) where it forms a stable complex with its specific escort protein, SCAP (SREBP cleavage-activating protein). ${ }^{21-23}$ When the amount of cholesterol decreases, the SREBP-SCAP complex translocates from ER to the Golgi, where the $\mathrm{NH}_{2}$-terminal SREBP is proteolytically processed to generate the mature form of SREBP. This activated SREBP moves to the nucleus where it promotes the expression of lipogenic genes. ${ }^{21-23} \mathrm{We}$ previously found that direct association of $25(\mathrm{OH}) \mathrm{D}_{3}(2)$ with SCAP suppresses the expression of SREBP-responsive genes by inducing proteolytic processing and ubiquitin-mediated degradation of SCAP. ${ }^{19}$ Therefore, $\mathrm{VD}_{3}$ metabolites are capable of influencing gene expression in mammalian cells through two independent pathways: VDR and SREBP pathways.

In the present study, we dissect the two independent activities by designing synthetic vitamin $\mathrm{D}_{3}$ analogs specific for VDR or SREBP, i.e., a VDR activator that lacks SREBP inhibitory activity, and an SREBP inhibitor devoid of VDR activity. Such chemical dissection permitted identification of one of the vitamin D-responsive genes as an SREBP-suppressed gene. 


\section{- Results and Discussion}

Discovery of a VDR-selective activator. In our effort to delineate $\mathrm{VD}_{3}$ activity, we initially searched for $\mathrm{VD}_{3}$ analogs that activate VDR but lack SREBP inhibitory activity. An in-house library of 250 vitamin D congeners $^{24-55}$ was screened for their ability to inhibit the activity of an SREBP-responsive luciferase reporter, in which expression of luciferase is controlled by three SREBP binding sites. We found that a series of vitamin D analogs, bearing alkyltriazole and alkyltetrazole substituents at C2 (4-9) (Fig. 2), displayed limited SREBP inhibitory activities (Fig. 3A). The ability of these six molecules ${ }^{32-34}$ to activate VDR was next examined by a VDR-responsive reporter assay (Fig. 3B). ${ }^{56}$ Comparison of the relative activities of the six compounds allowed us to select $2 \alpha \mathrm{C} 3$ Tet1 $(\mathbf{6})$ as the VDR-selective activator.
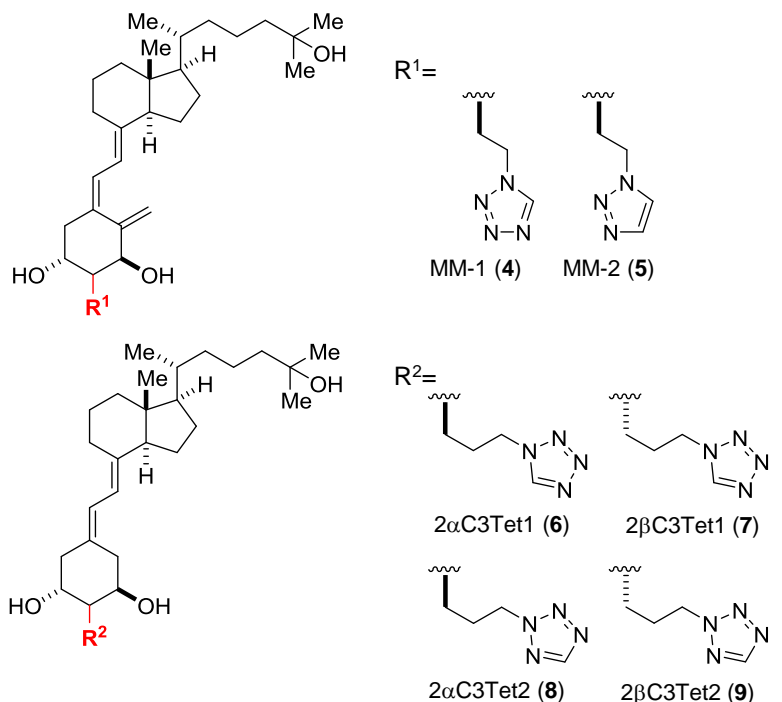

Figure 2. Structures of alkyltetrazole-substituted vitamin $\mathrm{D}_{3}$ derivatives at $\mathrm{C} 2$ position.

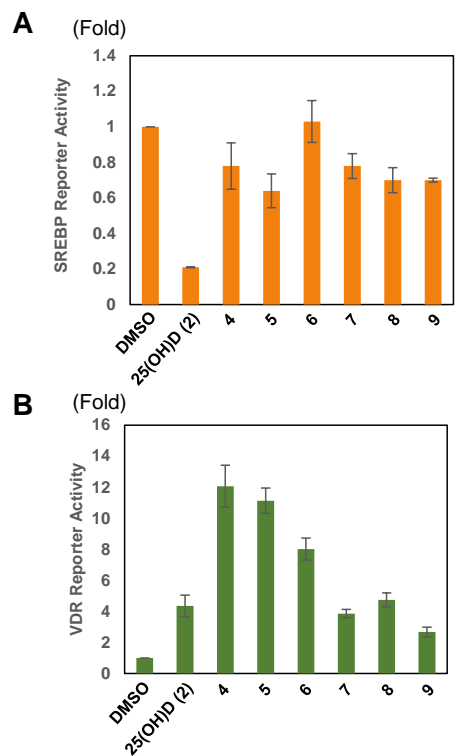

Figure 3. Effect of vitamin $D$ analogs bearing alkyltriazole- and alkyltetrazole-substituents at $C 2$ on SREBP or VDR activation. (A and B) Effect of $25(\mathrm{OH}) \mathrm{D}_{3}(\mathbf{2})$ and vitamin $\mathrm{D}_{3}$ analogs (compounds 4-9) on the ability of SREBPs (A) or VDR (B) to activate transcription of a luciferase reporter gene. CHO-K1 cells were transfected with the reporter gene in which the expression of luciferase was controlled by sterol-responsive element (SRE) (A) or vitamin D response element (VDRE) (B), and treated with $5 \mu \mathrm{M}$ of compounds in a medium B. Values are mean \pm SD. 
Discovery of an SREBP-selective inhibitor. We next searched for vitamin D analogs that inhibit SREBP but do not activate VDR. It is well known that (i) the hydroxy groups at $\mathrm{C} 1$ and $\mathrm{C} 3$ in $1 \alpha, 25(\mathrm{OH})_{2} \mathrm{D}_{3}(3)$ are critical for its interaction with $\mathrm{VDR},{ }^{57}$ and that (ii) the analogs without exomethylene at $\mathrm{C} 19$ in $\mathrm{A}$ ring, so-called 19-norvitamin D derivatives, tend to exhibit weaker VDR-dependent calcium effects and better stability than naturally occurring $\mathrm{VD}_{3} .{ }^{58}$ In addition, our preliminary observations revealed that the $1 \alpha$ NHBoc-25(OH)D $\mathrm{D}_{3}(\mathbf{1 0})$, bearing NHBoc group at $\mathrm{C} 1 \alpha$, maintained a similar SREBP inhibitory activity as those of $25(\mathrm{OH}) \mathrm{D}_{3}(2)$ and $1 \alpha, 25(\mathrm{OH})_{2} \mathrm{D}_{3}(\mathbf{3})$ (Fig. 4). ${ }^{19}$ With these observations in mind, we designed and synthesized 26 compounds (compounds 11-36) in which the $\mathrm{C} 1$ hydroxy group was replaced with nitrogen in the presence or absence of exomethylene at C19 (Fig. 4). ${ }^{59}$ The ability of compounds 11-36 to modulate SREBP and VDR activities were evaluated in the corresponding luciferase reporter gene assay (Fig. 5A and B). The $N$-alkylated derivatives 12-16 exhibited significant SREBP inhibitory activity at $5 \mu \mathrm{M}$ in CHO$\mathrm{K} 1$ cells. Among the compounds we tested, the $N$-sulfonamide 32a and the $N$-amide $\mathbf{2 6}$ and $\mathbf{2 9}$ substituted products inhibited SREBP as much as $25(\mathrm{OH}) \mathrm{D}_{3}(2)$ did (Fig. 5A). Subsequent VDR reporter assays revealed that the derivative of 32a, bearing $N$-Ts substituent with 19-nor type, showed the most potent inhibitory activity against SREBP with essentially no VDR agonistic activity. Discovery of 32a encouraged us to synthesize the rest of the seven possible regio- and stereoisomers at $\mathrm{C} 1$ and $\mathrm{C} 3$ in 32a, i.e., 32b-h (Fig. 4). ${ }^{44,59}$ Upon subsequent evaluation, all of the isomers of 32a exhibited potent SREBP inhibitory activity with limited VDR agonistic activity regardless of the regio- and stereochemistry at C1 and C3 (Fig. 5).

Optimization of compound 32. Further optimization of $\mathbf{3 2}$ was carried out to minimize its effect on VDR activity. Specifically, we prepared compounds 37c-f(Fig. 4), which were replaced with either a sulfonamide group or a fluorine atom $\mathrm{C} 1$ and $\mathrm{C} 3$ hydroxy group of $1 \alpha, 25(\mathrm{OH})_{2} \mathrm{D}_{3}(\mathbf{3}) \cdot{ }^{59}$ The biological activity of these four derivatives $\mathbf{3 7 c}$-f was evaluated in the luciferase reporter gene assays. The results revealed that all four derivatives exhibited an improved selectivity compared with that of 32a. There was no detectable VDR activation at $5 \mu \mathrm{M}$, while potent SREBP inhibitory activity was maintained at the same concentration (Fig. 5). Their structures were further optimized by modifying the $\mathrm{C} 17$ side chain in $\mathrm{CD}$ ring. In a number of vitamin D-based pharmaceuticals, the side chain is fluorinated to improve metabolic stability. ${ }^{60,61}$ Thus, the side chain of 37c-f was replaced with a 26,27-ditrifluoromethyl, similar to the clinically-used drug falecalcitriol, to yield compounds 38c-f (Fig. 4). ${ }^{59}$ Luciferase reporter gene assays revealed that all the isomers potently inhibit SREBP with limited VDR agonist activity regardless of the regio- and stereochemistry at $\mathrm{C} 1$ and $\mathrm{C} 3$ (Fig. 5). As mentioned, treatment with $25(\mathrm{OH}) \mathrm{D}_{3}$ induces the degradation of both SREBP and SCAP. Western blot analysis showed that compounds 38c, 38d and 38e induced the degradation similarly to $25(\mathrm{OH}) \mathrm{D}_{3}(\mathbf{2})$. Remarkably, 38d induced more degradation of SREBP and SCAP than $25(\mathrm{OH}) \mathrm{D}_{3}$, while the actin level was unchanged (Fig. 5C). From these findings, 38d was chosen as an SREBP-selective vitamin D analog. 

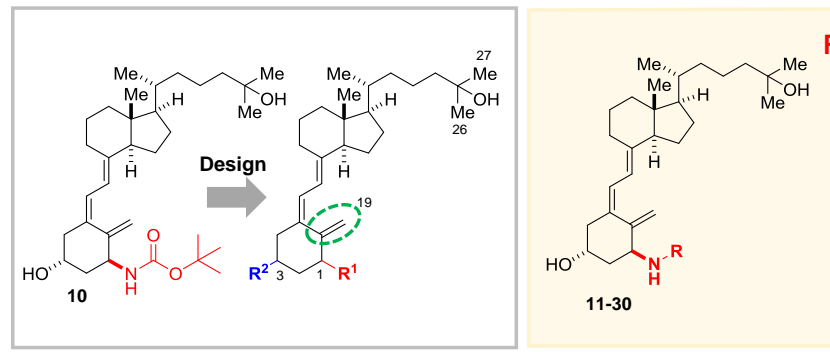

R:

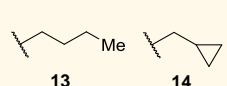<smiles>CCCCN1CCC(O)CC1</smiles>

"s"

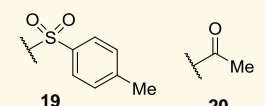

$\stackrel{1}{1}_{\mathrm{Et}}^{2}$

11-30

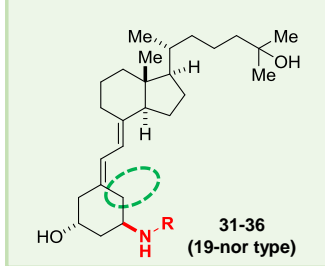

$\mathrm{R}::_{31}^{\mathrm{O}} \mathrm{s}_{\mathrm{Me}}^{\mathrm{O}}$
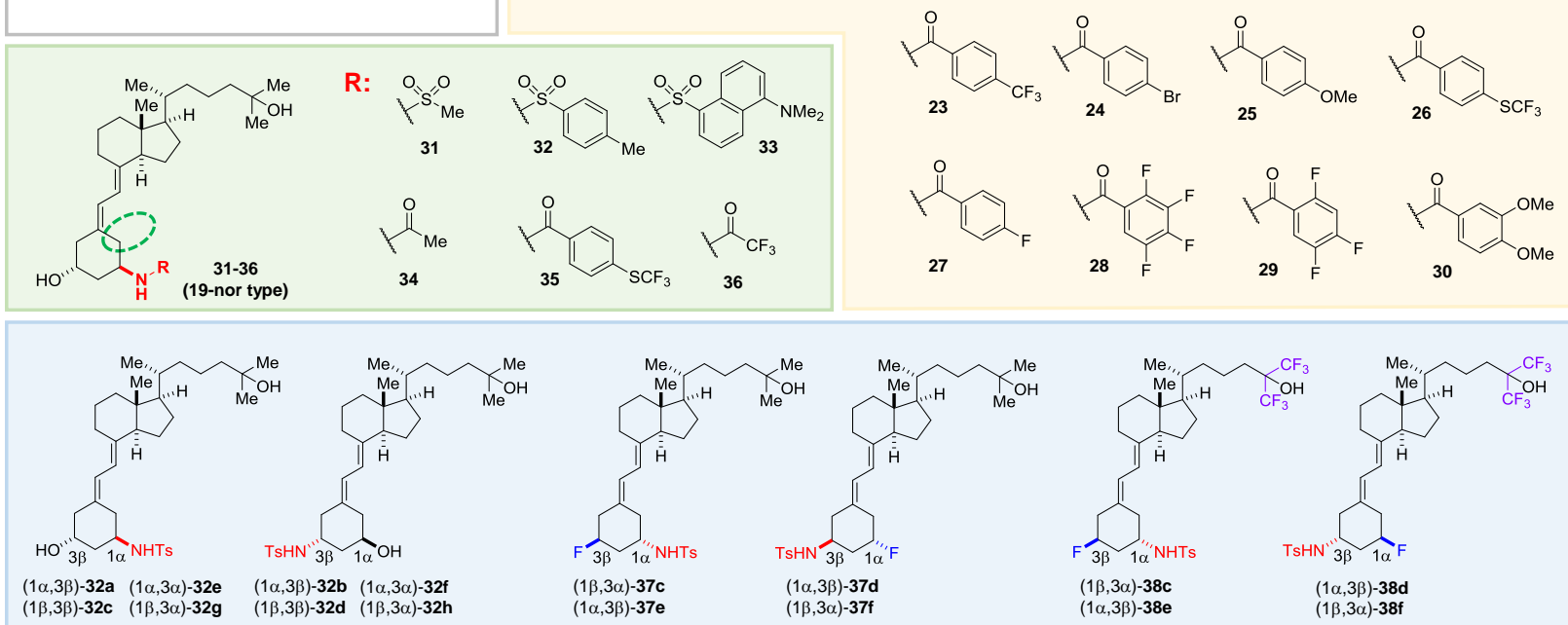

Figure 4 . Structures of $1 N$-substituted vitamin $\mathrm{D}_{3}$ and 19-norvitamin $\mathrm{D}_{3}$ derivatives. 

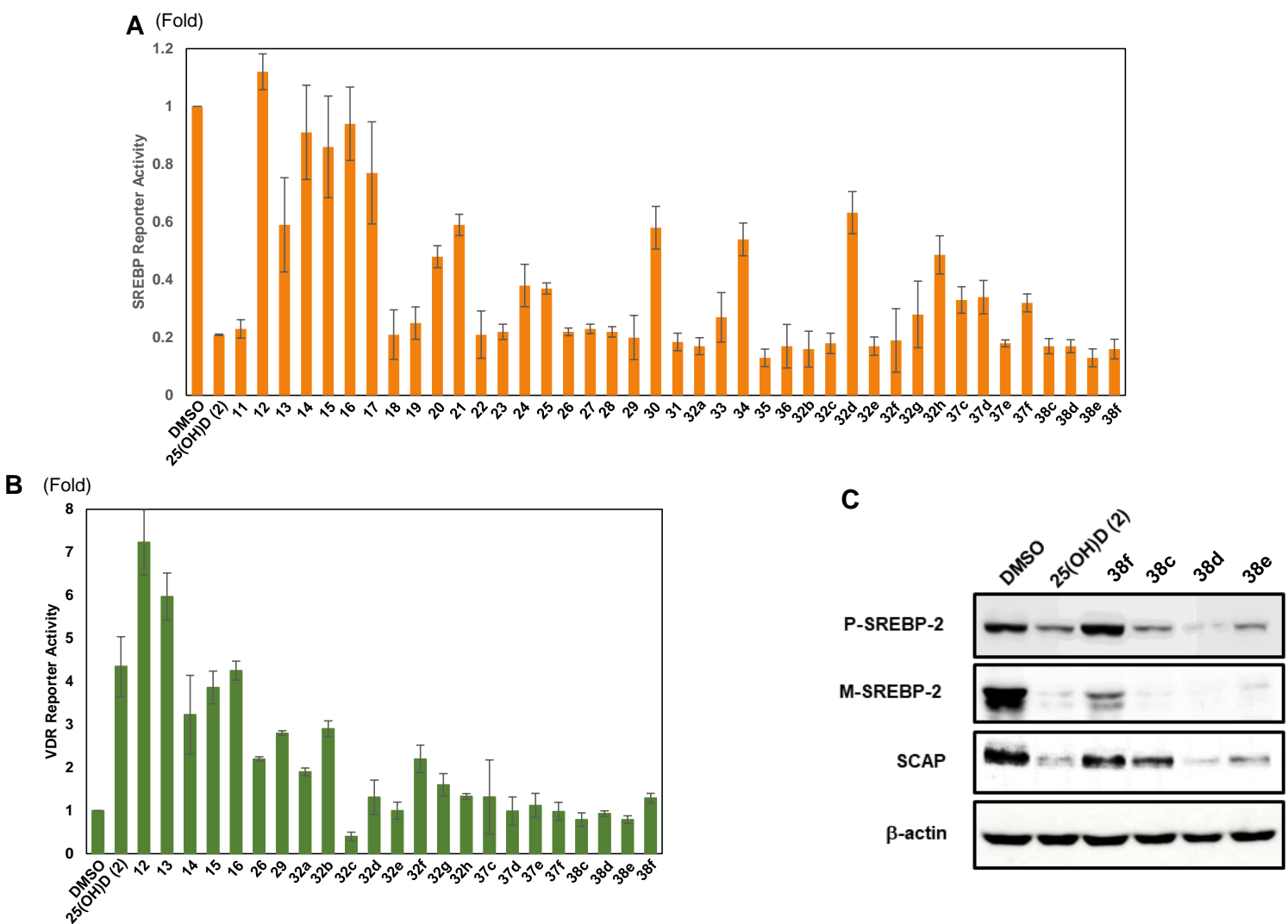

Figure 5. Effect of vitamin D analogs (compounds 11-36, 32b-h, 37c-f, 38c-f) on SREBP or VDR activation. (A and B) Effect of vitamin D analogs (compounds 12-16, 26, 29, 32a-h, 37c-f, 38c-f) on the ability of SREBPs (A) or VDR (B) to activate transcription of a luciferase reporter gene. CHO-K1 cells were transfected with each reporter gene, and treated with $5 \mu \mathrm{M}$ of compounds in a medium B. Values are mean $\pm \mathrm{SD}$. (C) Western blotting analysis of SREBP-2 and SCAP. CHO-K1 cells were treated with $5 \mu \mathrm{M}$ of compounds $38 \mathrm{c}-\mathbf{f}$ in a medium B. The levels of precursor (P) and mature (M) forms of SREBP-2 and SCAP were analyzed by western blotting.

Dissection of vitamin D-responsive genes. $1 \alpha, 25(\mathrm{OH})_{2} \mathrm{D}_{3}$ promotes the expression of numerous genes in mammalian cells. Most of these genes are considered to be induced primarily through the VDR pathway.,62${ }^{65}$ However, among those $\mathrm{VD}_{3}$-responsive genes, there may exist genes whose expression is down-regulated by SREBP independently of VDR activity. It is challenging to distinguish between these two types of genes using natural $\mathrm{VD}_{3}$ metabolites. Discrimination of these genes may be permitted by using our two vitamin $\mathrm{D}$ analogs, $\mathbf{6}$ and 38d. We comprehensively analyzed genes whose expression was promoted by $25(\mathrm{OH}) \mathrm{D}_{3}$ (2) in CHO-K1 cells. RNA sequencing (RNA-seq) analysis indicated that $25(\mathrm{OH}) \mathrm{D}_{3}$ induced the expression of 1,277 genes more than two-fold, including Cyp24al, a well-known VDR-responsive gene. ${ }^{66}$ Similar analysis was performed using compounds $\mathbf{6}$ and 38d, respectively. Many of the 1,277 genes were likewise induced by $\mathbf{6}$, indicating that these genes are controlled by VDR.

From the 1,277 vitamin D-responsive genes, we further selected the genes whose expression was induced more than two-fold by 38d but stayed within 0.5-1.5 fold with 6. A total of 209 genes were extracted as candidate genes that are controlled by SREBP rather than VDR (listed in a supplemental Excel file). Gene ontology (GO) analysis of the 209 genes indicate that the list of the candidate genes was enriched in those related to RNA binding proteins, including RNA polymerase III and aminoacyl-tRNA synthetases (Figures S1 and S2). RNA polymerase III, which transcribes DNA to synthesize ribosomal 5S rRNA and tRNA, and aminoacyl-tRNA synthetases are both essential for protein biosynthesis, raising the possibility that $25(\mathrm{OH}) \mathrm{D}_{3}$ upregulates protein biosynthesis through inhibition of SREBP.

Considering the lipogenic role of SREBP, we focused on six lipid metabolism-related genes (Table S3). Repeated qPCR experiments confirmed that Abcal (ATP Binding Cassette, Subfamily A, Member 1) and 
Soat1 (sterol $O$-acyltransferase 1) genes were induced by both $\mathbf{2}$ and 38d, but not by $\mathbf{6}$ (Fig. S3 and Fig. 6A). $A B C A 1$, a membrane transporter that excretes cholesterol out of the cell, is already known to be negatively regulated by SREBP. ${ }^{67}$ Hence, we selected Soat 1 gene for further investigation.

SOAT1 is an enzyme in the endoplasmic reticulum (ER) that converts cholesterol into cholesterol ester and stores it in oil droplets. ${ }^{68}$ To examine the role of SREBPs in the expression of SOAT1, their respective mRNA and protein levels were measured following the knock down of both Srebp-1 and Srebp-2 genes in CHO-K1 cells. Treatment with siRNA of SREBPs (siSREBP) decreased the mRNA levels of both SREBP1 and SREBP-2, and increased that of Soat 1 by about 3-fold; whereas the expression of SREBP-responsive genes, such as Hmgcr (HMGCoA reductase) and Fasn (fatty acid synthetase), were reduced (Fig. 6B). Western blot analysis also showed that siSREBP treatment increased the protein levels of SOAT1 (Fig. 6C). These results suggest that SREBPs suppress the expression of SOAT1.

The intracellular cholesterol level is maintained by the balance between biosynthesis and extracellular transport. It is known that SREBP tightly regulates these two processes by controlling relevant biosynthetic genes and transporter genes, including Abcal. ${ }^{21,22,69-71}$ Our findings suggested that SREBP also represses the intracellular storage of cholesterol by down-regulating the expression of SOAT1, an enzyme that converts cholesterol to cholesterol ester (Fig. 6D). The down-regulation of SOAT1 is thought to contribute in turn to the inactivation of SREBP through increased levels of free cholesterol. In fact, it has been reported that SREBP is inactivated when SOAT1 is pharmacologically or genetically suppressed in glioma cells. ${ }^{72}$ The SREBP-mediated suppression of SOAT1 would serve as a negative feedback mechanism for preventing excessive activation of SREBP, enabling SREBP to precisely regulate intracellular cholesterol level. 


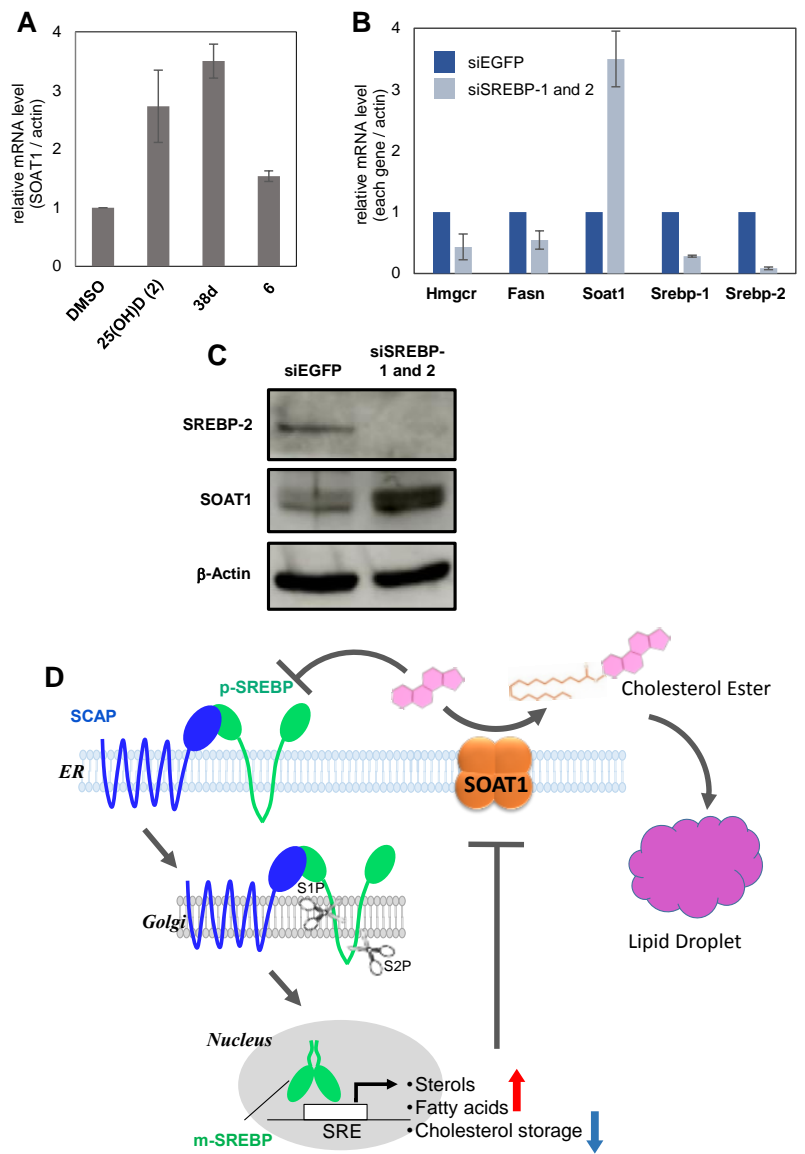

Figure 6. SOAT1 gene expression is negatively regulated by SREBPs. (A) CHO-K1 cells were incubated in medium B containing each compound for $24 \mathrm{hr}$. The mRNA level of SOAT1 was assessed by qPCR analysis. Data were analyzed by $\Delta \Delta$-Ct method with actin as reference control. (B and C) CHO-K1 cells were transfected with siRNAs targeting hamster Srebp-1 and Srebp-2 in medium A. After 24 hr incubation, the medium was replaced with medium B and the cells were further incubated for $24 \mathrm{hr}$. The mRNA level of Hmgcr, Fasn, Soat1, Srebp-1 or Srebp-2 was assessed by qPCR analysis. Data were analyzed by $\Delta \Delta$-Ct method with actin as reference control. (B). The protein level of SREBP-2, SOAT1 and $\beta$-Actin was analyzed by western blots (C). (D) A proposed model for SREBP's role in regulating cellular cholesterol storage.

\section{- Conclusions}

Vitamin D is a popular supplement highly regarded for its role and impact on various bodily health issues and diseases, including bone metabolism, immune response, central nervous system, cardiovascular function, metabolic diseases, and cancers. However, these benefits are likely to be the results of the intricate interplay of multiple vitamin D actions. The new set of pharmacological tools developed in the present study provides means for interrogating those vitamin D benefits and may serve as a starting point of designing vitamin D-based pharmaceuticals selective for each indication.

- Associated Content

Supporting Information

The Supporting Information is available.

- Author Information

Corresponding Authors

*E-mail: knaga@cc.tuat.ac.jp 
uesugi@scl.kyoto-u.ac.jp

akittaka@pharm.teikyo-u.ac.jp

\section{Author Contributions}

†These authors are contribiuted equally to this work.

\section{- Acknowledgments}

This work was supported by AMED-CREST, Japan Agency for Medical Research and Development, the International Collaborative Research Program of Institute for Chemical Research (2018-57 and 2017-53), and JSPS A3 Foresight Program. This work was inspired by the international and interdisciplinary environments of JSPS Core-to-Core Program of ACBI (Asian Chemical Biology Initiative).

\section{- References}

1. Fleet, J. C. Regulation of Intestinal Calcium and Phosphate Absorption. Vitamin D 2018, 329-342.

2. Samuel, S.; Sitrin, M. D. Vitamin D's role in cell proliferation and differentiation. Nutr. Rev. 2008, 66, S116-124.

3. Cantorna, M. T.; Zhu, Y.; Froicu, M.; Wittke, A. Vitamin D status, 1,25-dihydroxyvitamin $\mathrm{D}_{3}$, and the immune system. Am. J. Clin. Nutr. 2004, 80, 1717S-1720S.

4. Kato, S. The function of vitamin D receptor in vitamin D action. J. Biochem. 2000, 127, 717-722.

5. McDonnell, D. P.; Mangelsdorf, D. J.; Pike, J. W.; Haussler, M. R.; O'Malley, B. W. Molecular cloning of complementary DNA encoding the avian receptor for vitamin D. Science 1987, 235, 1214-1217.

6. Fleet, J. C. N., A. Rapid, membrane-initiated actions of 1,25 dihydroxyvitamin D: what are they and what do they mean? J. Nutr. 2004, 134, 3215-3218.

7. Valrance, M. E.; Welsh, J. Breast cancer cell regulation by high-dose Vitamin D compounds in the absence of nuclear vitamin D receptor. J. Steroid Biochem. Mol. Biol. 2004, 89-90, 221-225.

8. Nemere, I.; Farach-Carson, M. C.; Rohe, B.; Sterling, T. M.; Norman, A. W.; Boyan, B. D.; Safford, S. E. Ribozyme knockdown functionally links a $1,25(\mathrm{OH})_{2} \mathrm{D}_{3}$ membrane binding protein $(1,25 \mathrm{D} 3$-MARRS) and phosphate uptake in intestinal cells. Proc. Natl. Acad. Sci. USA 2004, 101, 7392-7397.

9. Slominski, A. T.; Kim, T. K.; Shehabi, H. Z.; Semak, I.; Tnag, E. K.; Nguyen, M. N.; Benson, H. A.; Korik, E.; Janjetovic, Z; Chen, J., Yates, C. R.; Postlethwaite, A.; Li, W.; Tuckey, R. C. In vivo evidence for a novel pathway of vitamin $\mathrm{D}_{3}$ metabolism initiated by $\mathrm{P} 450 \mathrm{scc}$ and modified by CYP27B1. FEBS 2012, 3901-3915.

10. Slominski, A. T.; Kim, T. -K.; Li, W.; Postlethwaite, A.; Tieu, E. W.; Tang, E. K. Y.; Tuckey, R. C. Detection of novel CYP11A1-derived secosteroids in the human epidermis and serum and pig adrenal gland. Sci. Rep. 2015, 5:14875.

11. Slominski, A.T.; Li, W.; Kim, T. K.; Semak, I.; Wang, J.; Zjawiony, J. K.; Tuckey, R. C. Novel activities of CYP11A1 and their potential physiological significance. J. Steroid Biochem Mol. Biol. 2015, 151, 2537. 
12. Slominski, A. T.; Kim, T. -K.; Hobrath, J. V.; Janjetovic, Z.; Oak, A. S. W.; Postlethwaite, A.; Lin, Z.; Li, W.; Takeda, Y.; Jetten, A. M.; Tuckey, R. C. Characterization of a new pathway that activates lumisterol in vivo to biologically active hydroxylumisterols. Sci. Rep. 2017, 7:11434.

13. Slominski, A. T.; Kim, T. K.; Takeda, Y.; Janjetovic, Z.; Brozyna, A. A.; Skobowiat, C.; Wang, J.; Postlethwaite, A.; Li, W.; Tuckey, R. C.; Jetten, A. M. ROR $\alpha$ and ROR $\gamma$ are expressed in human skin and serve as receptors for endogenously produced noncalcemic 20-hydroxy- and 20,23-dihydroxyvitamin D. FASEB J. 2014, 28, 2775-2789.

14. Slominski, A. T.; Kim, T. K.; Hobrath, J. V.; Oak, A. S. W.; Tang, E. K. Y.; Tieu, E. W.; Li, W. Tuckey, R. C.; Jetten, A. M. Endogenously produced nonclassical vitamin D hydroxy-metabolites act as "biased" agonists on VDR and inverse agonists on ROR $\alpha$ and ROR $\gamma$. J. Steroid Biochem Mol. Biol. 2017, 173, 4256.

15. Brożyna, A. A.; Jóźwicki, W.; Roszkowski, K.; Filipiak, J.; Slominski, A. T. Melanin content in melanoma metastases affects the outcome of radiotherapy. Oncotarget 2016, 7, 17844-17853.

16. Slominski, A. T.; Kim, T. K.; Janjetovic, Z.; Brożyna, A. A.; Żmijewski, M. A.; Xu, H.; Sutter, T. R.; Tuckey, R. C.; Jetten, A. M.; Crossman, D. K. Differential and Overlapping Effects of 20,23(OH) $2 \mathrm{D}_{3}$ and $1,25(\mathrm{OH})_{2} \mathrm{D} 3$ on Gene Expression in Human Epidermal Keratinocytes: Identification of $\mathrm{AhR}$ as an Alternative Receptor for 20,23(OH) 2 D $\mathrm{D}_{3}$. Int. J. Mol. Sci. 2018, 19(10):3072.

17. Shiizaki, K.; Hatamura, I.; Imazeki, I.; Moriguchi, Y.; Sakaguchi, T.; Saji, F.; Nakazawa, E.; Kato, S.; Akizawa, T.; Kusano, E. Improvement of impaired calcium and skeletal homeostasis in vitamin D receptor knockout mice by a high dose of calcitriol and maxacalcitol. Bone 2009, 45, 964-971.

18. Vanherwegen, A. S.; Ferreira, G. B.; Smeets, E.; Yamamoto, Y.; Kato, S.; Overbergh, L.; Gysemans, C.; Mathieu, C. The phenotype and function of murine bone marrow-derived dendritic cells is not affected

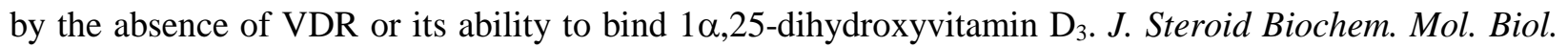
2016, 164, 239-245.

19. Asano, L.; Watanabe, M.; Ryoden, Y.; Usuda, K.; Yamaguchi, T.; Khambu, B.; Takashima, M.; Sato, S. I.; Sakai, J.; Nagasawa, K.; Uesugi, M. Vitamin D Metabolite, 25-Hydroxyvitamin D, Regulates Lipid Metabolism by Inducing Degradation of SREBP/SCAP. Cell Chem. Biol. 2017, 24, 207-217.

20. Brown, A. J.; Sun, L.; Feramisco, J. D.; Brown, M. S.; Goldstein, J. L. Cholesterol Addition to ER Membranes Alters Conformation of SCAP, the SREBP Escort Protein that Regulates Cholesterol Metabolism. Molecular Cell 2002, 10, 237-245.

21. Brown, M. S.; Goldstein, J. L., The SREBP Pathway: Regulation of Cholesterol Metabolism by Proteolysis of a Membrane-Bound Transcription Factor. Cell 1997, 89, 331-340.

22. Goldstein, J. L.; DeBose-Boyd, R. A.; Brown, M. S. Protein sensors for membrane sterols. Cell 2006, $124,35-46$.

23. Brown, M. S.; Goldstein, J. L. Cholesterol feedback: from Schoenheimer's bottle to Scap's MELADL. J. Lipid Res. 2009, 50, S15-27.

24. Honzawa, S.; Hirasaka, K.; Yamamoto, Y.; Peleg, S.; Fujishima, T.; Kurihara, M.; Saito, N.; Kishimoto, S.; Sugiura, T.; Waku, K.; Hiroaki, T. A.; Kittaka, A. Design, synthesis and biological evaluation of novel 
1 $\alpha, 25$-dihydroxyvitamin $\mathrm{D}_{3}$ analogues possessing aromatic ring on 2 alpha-position. Tetrahedron 2005, 61, 11253-11263.

25. Honzawa, S.; Takahashi, N.; Yamashita, A.; Sugiura, T.; Kurihara, M.; Arai, M. A.; Kato, S.; Kittaka, A., Synthesis of a $1 \alpha$-C-methyl analogue of 25 -hydroxyvitamin $\mathrm{D}_{3}$ : interaction with a mutant vitamin $\mathrm{D}$ receptor Arg274Leu. Tetrahedron 2009, 65, 7135-7145.

26. Kittaka, A.; Suhara, Y.; Takayanagi, H.; Fujishima, T.; Kurihara, M.; Takayama, H. A concise and efficient route to $2 \alpha$-(omega-hydroxyalkoxy)-1 $\alpha, 25$-dihydroxyvitamin $\mathrm{D}_{3}$ : Remarkably high affinity to vitamin D receptor. Org. Lett. 2000, 2, 2619-2622.

27. Saito, N.; Masuda, M.; Matsunaga, T.; Saito, H.; Anzai, M.; Takenouchi, K.; Miura, D.; Ishizuka, S.; Takimoto-Kamimura, M.; Kittaka, A. 24,24-dimethylvitamin $\mathrm{D}_{3}-26,23$-lactones and their $2 \alpha$ functionalized analogues as highly potent VDR antagonists. Tetrahedron 2004, 60, 7951-7961.

28. Saito, N.; Suhara, Y.; Kurihara, M.; Fujishima, T.; Honzawa, S.; Takayanagi, H.; Kozono, T.; Matsumoto, M.; Ohmori, M.; Miyata, N.; Takayama, H.; Kittaka, A. Design and efficient synthesis of $2 \alpha-$ (omega-hydroxyalkoxy)-1 $\alpha, 25$-dihydroxyvitamin D3 analogues, including 2-epi-ED-71 and their 20epimers with HL-60 cell differentiation activity. J. Org. Chem. 2004, 69, 7463-7471.

29. Sawada, D.; Katayama, T.; Tsukuda, Y.; Saito, N.; Saito, H.; Takagi, K.; Ochiai, E.; Ishizuka, S.; Takenouchi, K.; Kittaka, A. Synthesis of $2 \alpha$ - and $2 \beta$-substituted-14-epi-previtamin $\mathrm{D}_{3}$ and their genomic activity. Tetrahedron 2010, 66, 5407-5423.

30. Sawada, D.; Katayama, T.; Tsukuda, Y.; Saito, N.; Takano, M.; Saito, H.; Takagi, K.; Ochiai, E.; Ishizuka, S.; Takenouchi, K.; Kittaka, A. Synthesis of $2 \alpha$-substituted-14-epi-previtamin $\mathrm{D}_{3}$ and its genomic activity. Bioorg. Med. Chem. Lett. 2009, 19, 5397-5400.

31. Suhara, Y.; Nihei, K.; Kurihara, M.; Kittaka, A.; Yamaguchi, K.; Fujishima, T.; Konno, K.; Miyata, N.; Takayama, H. Efficient and versatile synthesis of novel $2 \alpha$-substituted $1 \alpha, 25$-dihydroxyvitamin D3 analogues and their docking to vitamin D receptors. J. Org. Chem. 2001, 66, 8760-8771.

32. Takano, M.; Higuchi, E.; Higashi, K.; Hirano, K.; Takeuchi, A.; Sawada, D.; Kittaka, A. Syntheis and Preliminary Biological Evaluation of 2-[3-(tetorazolyl)propyl]-1 $\alpha, 25$-dihydroxy-19-norvitamin $\mathrm{D}_{3}$. Heterocycles 2015, 90, 1274-1287.

33. Takano, M.; Yasuda, K.; Higuchi, E.; Tohyama, E.; Takeuchi, A.; Sakaki, T.; Kittaka, A. Synthesis, metabolism, and biological activity of 2-[3-(tetrazolyl)propyl]-1 $\alpha, 25$-dihydroxy-19-norvitamin D3. $J$. Steroid Biochem. Mol. Biol. 2016, 164, 40-44.

34. Matsuo, M.; Hasegawa, A.; Takano, M.; Saito, H.; Kakuda, S.; Chida, T.; Takagi, K.; Ochiai, E.; Horie, K.; Harada, Y.; Takimoto-Kamimura, M.; Takenouchi, K.; Sawada, D.; Kittaka, A. Synthesis of $2 \alpha-$ heteroarylalkyl active vitamin $\mathrm{D}_{3}$ with therapeutic effect on enhancing bone mineral density in vivo. ACS Med. Chem. Lett. 2013, 4, 671-674.

35. Ono, K.; Yoshida, A.; Saito, N.; Fujishima, T.; Honzawa, S.; Suhara, Y.; Kishimoto, S.; Sugiura, T.; Waku, K.; Takayama, H.; Kittaka, A. Efficient synthesis of 2-modified 1 $\alpha, 25$-dihydroxy-19-norvitamin D3 with Julia olefination: high potency in induction of differentiation on HL-60 cells. J. Org. Chem. 2003, 68, 7407-7415. 
36. Honzawa, S.; Yamamoto, Y.; Yamashita, A.; Sugiura, T.; Kurihara, M.; Arai, M. A.; Kato, S.; Kittaka, A. The $2 \alpha$-(3-hydroxypropyl) group as an active motif in vitamin $\mathrm{D}_{3}$ analogues as agonists of the mutant vitamin D receptor (Arg274Leu). Bioorg. Med. Chem. 2008, 16, 3002-3024.

37. Saito, N.; Matsunaga, T.; Saito, H.; Anzai, M.; Takenouchi, K.; Miura, D.; Namekawa, J.; Ishizuka, S.; Kittaka, A. Further synthetic and biological studies on vitamin D hormone antagonists based on C24alkylation and $\mathrm{C} 2 \alpha$-functionalization of 25-dehydro- $1 \alpha$-hydroxyvitamin $\mathrm{D}_{3}$-26,23-lactones. J. Med. Chem. 2006, 49, 7063-7075.

38. Kato, Y.; Hashimoto, Y.; Nagasawa, K. Novel Heteroatom-containing Vitamin D3 Analogs: Efficient Synthesis of 1 $\alpha, 25$-Dihydroxyvitamin $\mathrm{D}_{3}$-26,23-lactam. Molecules 2003, 8, 488-499.

39. Hosoda, S.; Tanatani, A.; Wakabayashi, K.; Nakano, Y.; Miyachi, H.; Nagasawa, K.; Hashimoto, Y. Ligands with dual vitamin $\mathrm{D}_{3}$-agonistic and androgen-antagonistic activities. Bioorg. Med. Chem. Lett. 2005, 15, 4327-4331.

40. Nakano, Y.; Kato, Y.; Imai, K.; Ochiai, E.; Namekawa, J.; Ishizuka, S.; Takenouchi, K.; Tanatani, A.; Hashimoto, Y.; Nagasawa, K. Practical synthesis and evaluation of the biological activities of $1 \alpha-$ dihydroxyvitamin D3 antagonists, 1 $\alpha, 25$-dihydroxyvitamin D3-26,23-lactams. Designed on the basis of the helix 12-folding inhibition hypothesis. J. Med. Chem. 2006, 49, 2398-2406.

41. Cho, K.; Uneuchi, F.; Kato-Nakamura, Y.; Namekawa, J.; Ishizuka, S.; Takenouchi, K.; Nagasawa, K. Structure-activity relationship studies on vitamin D lactam derivatives as vitamin D receptor antagonist. Bioorg. Med. Chem. Lett. 2008, 18, 4287-4290.

42. Nagasawa, K.; Kato-Nakamura, Y.; Ishizuka, S.; Saitoh, H.; Namekawa, J.-i.; Takenouchi, K. Synthesis and Biological Activities of VDR Antagonists; 25-Modified 1 $\alpha, 25$-Dihdyroxyvitamin $\mathrm{D}_{3}$-26,23-lactam (DLAM) Derivatives. Heterocycles 2009, 7, 507-520.

43. Toyoda, A.; Nagai, H.; Yamada, T.; Moriguchi, Y.; Abe, J.; Tsuchida, T.; Nagasawa, K. Novel synthesis of 1 1,25-dihydroxy-19-norvitamin D from 25-hydroxyvitamin D. Tetrahedron 2009, 65, 10002-10008.

44. Usuda, K.; Biswas, T.; Yamaguchi, T.; Akagi, Y.; Yasui, K.; Uesugi, M.; Shimizu, I.; Hosokawa, S.; Nagasawa, K. Synthesis of Diastereomers of 1,3-cis-25-Dihydroxy-19-norvitamin $\mathrm{D}_{3}$. Chem. Pharm. Bull. 2016, 64, 1190-1195.

45. Abe, J.; Nagai, Y.; Higashikuni, R.; Iida, K.; Hirokawa, T.; Nagai, H.; Kominato, K.; Tsuchida, T.; Hirata, M.; Inada, M.; Miyaura, C.; Nagasawa, K. Synthesis of vitamin $\mathrm{D}_{3}$ derivatives with nitrogen-linked substituents at A-ring C-2 and evaluation of their vitamin D receptor-mediated transcriptional activity. Org. Biomol. Chem. 2012, 10, 7826-7839.

46. Akagi, Y.; Usuda, K.; Tanami, T.; Yasui, K.; Asano, L.; Uesugi, M.; Nagasawa, K. Synthesis of 1 $\alpha$ and 1 $\beta$-amino-25-hydroxyvitamin $\mathrm{D}_{3}$. Asian J. Org. Chem. 2016, 5, 1247-1252.

47. Biswas, T.; Akagi, Y.; Usuda, K.; Yasui, K.; Shimizu, I.; Okamoto, M.; Uesugi, M.; Hosokawa, S.; Nagasawa, K. Synthesis of 24,24-Difluoro-1,3-cis-25-dihydroxy-19-norvitamin $\mathrm{D}_{3}$ Derivatives and Evaluation of Their Vitamin D Receptor-Binding Affinity. Biolog. Pharm. Bull. 2016, 39, 1387-1391.

48. Kato, Y.; Nakano, Y.; Sano, H.; Tanatani, A.; Kobayashi, H.; Shimazawa, R.; Koshino, H.; Hashimoto, Y.; Nagasawa, K. Synthesis of 1 $\alpha, 25$-dihydroxyvitamin $\mathrm{D}_{3}$-26,23-lactams (DLAMs), a novel series of $1 \alpha$, 25,-dihydroxyvitamin D3 antagonist. Bioorg. Med. Chem. Lett. 2004, 14, 2579-2583. 
49. Nagai, Y.; Tanami, T.; Abe, J.; Nagai, H.; Hamamizu, T.; Kominato, K.; Iida, K.; Nagasawa, K. Synthesis of 19-Nor-Vitamin D A-Ring Synthons via Ring-Closing Olefin Metathesis. Asian J. Org. Chem. 2014, 3, 994-999.

50. Otero, R.; Ishizawa, M.; Numoto, N.; Ikura, T.; Ito, N.; Tokiwa, H.; Mourino, A.; Makisjima, M.; Yamada, S., 25 S-Adamantyl-23-yne-26,27-dinor-1 $\alpha, 25$-dihydroxyvitamin D3: Synthesis, Tissue Selective Biological Activities, and X-ray Crystal Structural Analysis of Its Vitamin D Receptor Complex. J. Med. Chem. 2018, 61, 6658-6673.

51. Otero, R.; Seoane, S.; Sigueiro, R.; Belorusova, A.; Maestro, A. M.; Perez-Fernandez, R.; Rochel, N.; Mourino, A. Carborane-based design of a potent vitamin D receptor agonist. Chem. Sci. 2016, 7, 10331037.

52. Yoshizawa, M.; Itoh, T.; Hori, T.; Kato, A.; Anami, Y.; Yoshimoto, N.; Yamamoto, K. Identification of the Histidine Residue in Vitamin D Receptor That Covalently Binds to Electrophilic Ligands. J. Med. Chem. 2018, 61, 6339-6349.

53. Duffy, M. J.; Murray, A.; Synnott, N. C.; O’Donovan, N.; Crown, J. Vitamin D analogues: Potential use in cancer treatment. Crit. Rev. Oncol. Hemat. 2017, 112, 190-197.

54. Leyssene, C.; Verlinden, L.; Verstuyf, A. The future of vitamin D analogs. Front. Physiol. 2014, https://doi.org/10.3389/fphys.2014.00122.

55. Posner, G. H.; Kahraman, M. Organic Chemistry of Vitamin D Analogues (Deltanoids). Eur. J. Org. Chem. 2003, 3889-3895.

56. All the results of SREBP and VDR assays were compared with $25(\mathrm{OH}) \mathrm{D}_{3}(2)$.

57. Mizwicki, M. T.; Bula, C. M.; Bishop, J. E.; Norman, A. W. A perspective on how the Vitamin D sterol/Vitamin D receptor (VDR) conformational ensemble model can potentially be used to understand the structure-function results of A-ring modified Vitamin D sterols. J. Steroid Biochem. Mol. Biol. 2005, 97, 69-82.

58. Perlman, K. L.; Sicinski, R. R.; Schnoes, H. K.; DeLuca, H. F. 1 1,25-dihydroxy-19-nor-vitamin D3, a novel vitamin D-related compound with potential therapeutic activity. Tetrahedron Lett. 1990, 31, 18231824.

59. Synthesis of compounds, see supporting information.

60. Tanaka, Y.; DeLuca, H. F.; Kobayashi, Y.; Ikekawa, N. 26,26,26,27,27,27-Hexafluoro-1,25dihydroxyvitamin $\mathrm{D}_{3}$ : A highly potent, long-lasting analog of 1,25-dihydroxyvitamin $\mathrm{D}_{3}$. Archives of Biochem. Biophy. 1984, 229, 348-354.

61. Komuro, S.; Sato, M.; Kanamaru, H., Disposition and metabolism of F6-1 $\alpha, 25(\mathrm{OH}) 2$ vitamin D3 and $1 \alpha, 25(\mathrm{OH})_{2}$ vitamin $\mathrm{D}_{3}$ in the parathyroid glands of rats dosed with tritium-labeled compounds. Drug Metab. Dispos. 2003, 31, 973-978.

62. Dwivedi, P. P.; Omdahl, J. L.; Kola, I.; Hume, D. A.; May, B. K. Regulation of rat cytochrome P450C24 (CYP24) gene expression. Evidence for functional cooperation of Ras-activated Ets transcription factors with the vitamin D receptor in 1,25-dihydroxyvitamin D3-mediated induction. J. Biol. Chem. 2000, 275, 47-55. 
63. Neme, A.; Seuter, S.; Malinen, M.; Nurmi, T.; Tuomainen, T. P.; Virtanen, J. K.; Carlberg, C. In vivo transcriptome changes of human white blood cells in response to vitamin D. J. Steroid Biochem. Mol. Biol. 2018, doi.org/10.1016/j.jsbmb.2018.11.019.

64. Palmer, H. G.; Sanchez-Carbayo, M.; Ordonez-Moran, P.; Larriba, M. J.; Cordon-Cardo, C.; Munoz, A. Genetic signatures of differentiation induced by $1 \alpha, 25$-dihydroxyvitamin $\mathrm{D}_{3}$ in human colon cancer cells. Cancer research 2003, 63, 7799-806.

65. Welsh, J.; Wietzke, J. A.; Zinser, G. M.; Smyczek, S.; Romu, S.; Tribble, E.; Welsh, J. C.; Byrne, B.; Narvaez, C. J. Impact of the Vitamin $\mathrm{D}_{3}$ receptor on growth-regulatory pathways in mammary gland and breast cancer. J. Steroid Biochem. Mol. Biol. 2002, 83, 85-92.

66. Ohyama, Y.; Ozono, K.; Uchida, M.; Yoshimura, M.; Shinki, T.; Suda, T.; Yamamoto, O. Functional Assessment of Two Vitamin D-responsive Elements in the Rat 25-Hydroxyvitamin $\mathrm{D}_{3}$ 24-Hydroxylase Gene. J. Biol. Chem. 1996, 271, 30381-30385.

67. Zeng, L.; Liao, H.; Liu, Y.; Lee, T. S.; Zhu, M.; Wang, X.; Stemerman, M. B.; Zhu, Y,; Shyy, J. Y., Sterol-responsive element-binding protein (SREBP) 2 down-regulates ATP-binding cassette transporter A1 in vascular endothelial cells: a novel role of SREBP in regulating cholesterol metabolism., J. Biol. Chem. 2004, 47, 48801-48807.

68. Pol, A.; Gross, S. P.; Parton, R. G. Biogenesis of the multifunctional lipid droplet: lipids, proteins, and sites. J. Cell Biol. 2014, 204, 635-646.

69. Tamehiro, N.; Shigemoto-Mogami, Y.; Kakeya, T.; Okuhira, K.; Suzuki, K.; Sato, R.; Nagao, T.; Nishimaki-Mogami, T. Sterol regulatory element-binding protein-2- and liver X receptor-driven dual promoter regulation of hepatic $\mathrm{ABC}$ transporter $\mathrm{A} 1$ gene expression: mechanism underlying the unique response to cellular cholesterol status. J. Biol. Chem. 2007, 282, 21090-21099.

70. Horie, T.; Ono, K.; Horiguchi, M.; Nishi, H.; Nakamura, T.; Nagao, K.; Kinoshita, M.; Kuwabara, Y.; Marusawa, H.; Iwanaga, Y.; Hasegawa, K.; Yokode, M.; Kimura, T.; Kita, T. MicroRNA-33 encoded by an intron of sterol regulatory element-binding protein 2 (Srebp2) regulates HDL in vivo. Proc. Natl. Acad. Sci. USA 2010, 107, 17321-17326.

71. Najafi-Shoushtari, S. H.; Kristo, F.; Li, Y.; Shioda, T.; Cohen, D. E.; Gerszten, R. E.; Naar, A. M. MicroRNA-33 and the SREBP host genes cooperate to control cholesterol homeostasis. Science 2010, 328, 1566-1569.

72. Geng, F.; Cheng, X.; Wu, X.; Yoo, J. Y.; Cheng, C.; Guo, J. Y.; Mo, X.; Ru, P.; Hurwitz, B.; Kim, S. H.; Otero, J.; Puduvalli, V.; Lefai, E.; Ma, J.; Nakano, I.; Horbinski, C.; Kaur, B.; Chakravarti, A.; Guo, D. Inhibition of SOAT1 Suppresses Glioblastoma Growth via Blocking SREBP-1-Mediated Lipogenesis. Clin. Cancer Res. 2016, 22, 5337-5348. 